\title{
Pemanfaatan Fly Ash Sebagai Substitusi Semen Dan Batu Gamping Sebagai Agregat Pada Beton
}

\author{
Windi Desliono*1, Herman Parung ${ }^{\star 2}$, Suryanti Rapang Tonapa ${ }^{\star 3}$ \\ *1 Mahasiswa Program Studi Teknik Sipil, Universitas Kristen Indonesia Paulus, Makassar \\ Email deslionowindy@gmail.com \\ *2 Dosen Program Studi Teknik Sipil, Universitas Kristen Indonesia Paulus, Makassar \\ Email parungherman@gmail.com \\ *3 Dosen Program Studi Teknik Sipil, Universitas Kristen Indonesia Paulus, Makassar \\ Email suryantirt19@gmail.com
}

\begin{abstract}
ABSTRAK
Fly Ash adalah limbah hasil pembakaran batubara dan salah satu mineral campuran pozzolan yang terdapat di Indonesia. Inovasi teknologi beton yang ramah lingkungan untuk mengurangi penggunaan semen dan batu kali, yaitu memanfaatkan Fly ash sebagai substitusi semen dan batu gamping sebagai agregat untuk campuran beton. Penelitian ini bertujuan untuk mengetahui sifat mekanik beton dan persentase optimum pemakain Fly ash pada campuran beton dengan batu gamping sebagai agregat kasar. Persentase Fly ash yang digunakan bervariasi, yaitu $0 \%, 10 \%, 15 \%$, dan $20 \%$. Uji kuat tekan dilaksanakan waktu beton berumur 7 dan 21 dan 28 hari dengan kuat rencana $25 \mathrm{MPa}$. Pada uji kuat lentur dan tarik belah dillakukan pada waktu beton 28 hari. Penelitian ini menggunakan silinder berukuran $150 \mathrm{x}$ $300 \mathrm{~mm}$ sebanyak 48 buah, balok berukuran $150 \times 150 \times 600 \mathrm{~mm}$ sebanyak 12 buah, dilaksanakan pada Laboratorium Struktur Teknik Sipil, Universitas Kristen Indonesia Paulus Makassar. Hasil observasi menunjukkan bahwa adanya pengaruh penggunaan Fly ash sebagai substitusi semen dengan batu gamping sebagai agregat untuk beton, menghasilkan beton dengan kuat tekan, kuat lentur, dan kuat tarik belah beton, yang maksimal berturut-turut adalah $27,56 \mathrm{MPa}, 2,50 \mathrm{MPa}$, dan 4,68 MPa terhadap beton normal dengan persentase penggunaan Fly ash optimum 15\%.
\end{abstract}

Kata kunci: Fly Ash, Batu Gamping, Kuat Tekan, Kuat Tarik Belah, Kuat Lentur

\begin{abstract}
Fly Ash is a waste combustion combustion system and one of the pozzolanic mixed minerals found in Indonesia. An environmentally friendly concrete technology innovation to reduce the use of cement and river stone, namely utilizing Fly ash as a substitute for cement and limestone as an aggregate for concrete mixtures. This study aims to see the mechanical properties of concrete and the optimum proportion of Fly ash in the concrete mixture with limestone as coarse aggregate. The percentage of Fly ash used varies, namely $0 \%, 10 \%, 15 \%$, and $20 \%$. Concrete compressive strength testing is carried out when the concrete is 7 days, 21 days, and 28 days old with a compressive strength plan of $25 \mathrm{MPa}$. For the flexural strength and split tensile strength test, it is carried out when the concrete is 28 days old. The research used 48 cylinders $150 \times 300 \mathrm{~mm}, 12$ beams measuring $150 \times 150 \times 600 \mathrm{~mm}$, carried out at the Laboratory of Civil Engineering Structures, Paulus Christian University of Indonesia, Makassar. The observation results show that the influence of Fly ash as a substitute for cement with limestone aggregate for concrete, produces concrete with compressive strength, flexural strength, and tensile strength, the maximum is $27.56 \mathrm{MPa}, 2.50 \mathrm{MPa}$, respectively. and 4.68 MPa for normal concrete with the optimum use proportion of Fly ash $15 \%$.
\end{abstract}

\section{Keywords: Fly Ash, Limestone, Compressive Strength, Tensile Strength, Flexural Strength}

\section{PENDAHULUAN}

Beton adalah suatu bahan bangunan yang terdiri dari semen, air, kerikil, ada atau tanpa material tambahan bila diperlukan. Beton banyak digunakan dalam pekerjaan konstruksi karena mempunyai banyak keunggulan seperti harga yang sangat murah, kuat tekan yang tinggi dan biaya perawatan yang rendah. Agregat dalam beton berguna sebagai pengisi. Komposisi agregat halus dan kasar pada beton berkisar 70$80 \%$ dari total material campuran beton. Hal ini sangat penting karena agregat berpengaruh pada mutu beton. Keterbatasan kehalusan butiran semen menjadi kendala utama dalam menghasilkan mutu beton. Sebab itu, berbagai penelitian dilakukan untuk mencari bagaimana cara penggunan semen sebagai campuran 
Paulus Civil Engineering Journal Jurnal Teknik Sipil UKI-Paulus Makassar https://doi.org/10.52722/pcej.v3i2.3211
Volume 3 No.2, Juni 2021

e-ISSN 2775-4529

p-ISSN 2775-8613 pembuatan beton. Pada pembakaran batubara PLTU terdapat limbah padat yaitu fly ash yaitu partikel abu yang terbawa oleh gas buangan yang berwarna abu-abu kehitaman.

Menurut SNI.03.2847.2013, beton adalah campuran semen Portland dan semen hidraolik lainya, agregat halus, agregat kasar, dan air, dengan atau tanpah bahan tambah yang membentuk massa padat. [1] Ukuran yang mempengaruhi mutu suatu beton yaitu jumlah semen yang digunakan, serta kekuatan agregat yang digunakan. Bentuk agregat bermacammacam ada yang bulat, ada yang datar, hal inilah yang akan memengaruhi workability campuran beton saat pengadukan.

\section{Material Penyusun Beton}

\section{Semen Portland (PCC)}

Salah satu material penyususun beton adalah semen Portland dari hasil penggilingan terak Portland dan plester semen yang banyak mengandung bahan anorganik seperti terak tanur, senyawa silikat, pozolan, batu gampig. Total bahan anorganik yang ada ialah $6-35 \%$ dari masa komposit semen Portland.

\section{Agregat halus}

Agregat halus menurut SNI 03.2847.2013 yaitu agregat yang memiliki diameter butir paling besar yaitu $5,0 \mathrm{~mm}$. Agregat halus dapat berupa pasir yang berguna sebagai pengisi. Agregat halus yang baik ialah mempunyai kandungan lumpur yang sedikit atau tidak boleh lebih dari $5 \%$ berat kering.

Tabel 1. Syarat susunan agregat halus

\begin{tabular}{ccccc}
\hline $\begin{array}{c}\text { Standar } \\
\begin{array}{c}\text { Saringan } \\
(\mathrm{cm})\end{array}\end{array}$ & $\begin{array}{c}\text { Juea 1 } \\
\text { (kasar) }\end{array}$ & $\begin{array}{c}\text { Area 2 } \\
\text { (Agak } \\
\text { Kasar) }\end{array}$ & $\begin{array}{c}\text { Area 3 } 3 \\
\text { (Agak } \\
\text { Halus) }\end{array}$ & $\begin{array}{c}\text { Area 4 } \\
\text { (Halus) }\end{array}$ \\
\hline 0,96 & 100 & 100 & 100 & 100 \\
0,48 & $90-100$ & $90-100$ & $90-100$ & $95-100$ \\
0,24 & $60-95$ & $75-100$ & $85-00$ & $95-100$ \\
0,12 & $30-70$ & $55-100$ & $75-100$ & $90-100$ \\
0,06 & $15-34$ & $35-59$ & $60-79$ & $80-100$ \\
0,03 & $5-20$ & $8-30$ & $12-40$ & $5-50$ \\
0,01 & $0-10$ & $0-10$ & $0-10$ & $0-15$ \\
\hline
\end{tabular}

Tabel 2. Detail spesifik agegat halus

\begin{tabular}{lcc}
\hline $\begin{array}{l}\text { Karakteristik } \\
\text { Agrgat halus }\end{array}$ & $\begin{array}{c}\text { Interval } \\
\text { Batas }\end{array}$ & Panduan \\
\hline Kadar lumpur, \% & $0,2-6,0$ & SNI 03.4I42.1996
\end{tabular}

\begin{tabular}{lcl}
\hline Zat organik, & $<$ No.3 & ASTM-C40 \\
$\begin{array}{l}\text { Takaran air, \% } \\
\text { Jumlah volume }\end{array}$ & $3-5$ & SNI 03.1971.1990 \\
$\begin{array}{l}\text { padat, kg/ltr } \\
\text { Jumlah volume }\end{array}$ & $1,40-1,90$ & SNI 03.4840.1998 \\
$\begin{array}{l}\text { gembur, kg/ltr } \\
\text { Absorpsi,\% }\end{array}$ & $0,20-2,00$ & SNI 03.4840.1998 \\
$\begin{array}{l}\text { Berat jenis (SSD) } \\
\begin{array}{l}\text { Modulus } \\
\text { kehalusan }\end{array}\end{array}$ & $1,6-3,2,00$ & SNI 1970.2008 \\
& $2,20-3,10$ & SNI 1970.2008 03.1968.1990 \\
\hline
\end{tabular}

\section{Agregat kasar}

Agregat kasar ialah hasil pecahan alami kerikil dan batuan maupun bahan yang diperoleh dari industri pemecah batu dan memiliki dimensi butiran antara 5 milimeter hingga 40 milimeter, menurut SNI 03.2847.2013. Agregat kasar yang bisa menghasilkan beton kualitas tinggi adalah agregat kasar yang mempunyai ukuran lebih besar dari pada 4,75 milimeter, bersih dari faktor organik, memiliki butiran keras serta tidak berpori, dan tidak mempunyai lumpur lebih dari $10 \%$ berat kering.

Tabel 3. Hasil analisa proporsi saringan agregat kasar

\begin{tabular}{cccc}
\hline \multirow{2}{*}{$\begin{array}{c}\text { Standar Saringan } \\
(\mathrm{cm})\end{array}$} & \multicolumn{3}{c}{ Jumlah Lolos (\%) } \\
& $10 \mathrm{~mm}$ & $20 \mathrm{~mm}$ & $40 \mathrm{~mm}$ \\
\hline 7,8 & 100 & - & - \\
3,8 & $95-100$ & 100 & - \\
1,9 & $35-70$ & $95-100$ & 100 \\
0,96 & $10-40$ & $30-60$ & $50-85$ \\
0,48 & $0-5$ & $0-10$ & $0-10$ \\
\hline
\end{tabular}

Tabel 4. Detail spesifik agregat kasar

\begin{tabular}{|c|c|c|}
\hline $\begin{array}{l}\text { Spesifik } \\
\text { Agregat } \\
\text { Kasar }\end{array}$ & $\begin{array}{r}\text { Interval } \\
\text { Batas }\end{array}$ & Panduan \\
\hline $\begin{array}{l}\text { Kandungan } \\
\text { lumpur, \% }\end{array}$ & $0,2-1,0$ & $\begin{array}{l}\text { SNI 03- } \\
4142-1996\end{array}$ \\
\hline $\begin{array}{l}\text { Kandungan } \\
\text { air, \% }\end{array}$ & $0,5-2,0$ & $\begin{array}{l}\text { SNI 03- } \\
1971-1990\end{array}$ \\
\hline $\begin{array}{l}\text { Jumlah volume } \\
\text { padat, kg/ltr }\end{array}$ & $1,40-1,90$ & $\begin{array}{l}\text { SNI 03- } \\
4804-1998\end{array}$ \\
\hline $\begin{array}{l}\text { Jumlah volume } \\
\text { gembur, kg/ltr }\end{array}$ & $1,40-1,90$ & $\begin{array}{l}\text { SNI 03- } \\
4804-1998\end{array}$ \\
\hline Ábsorpsi, \% & $0,20-2,00$ & $\begin{array}{l}\text { SNI 1969- } \\
2008\end{array}$ \\
\hline Berat jenis SSd & $1,60-3,20$ & $\begin{array}{l}\text { SNI 1969- } \\
2008\end{array}$ \\
\hline
\end{tabular}

Air

Air digunakan agar ada proses reaksi kimia pada proses hidrasi. Menurut Paul Nugraha, Air yang 
Paulus Civil Engineering Journal Jurnal Teknik Sipil UKI-Paulus Makassar https://doi.org/10.52722/pcej.v3i2.3211
Volume 3 No.2, Juni 2021

e-ISSN 2775-4529

p-ISSN 2775-8613 diperlukan banyak dipengruhi oleh faktor di bawah ini : [2]

1. Dimensi agregat maksimal: diameter membesar.

2. Wujud butir: wujud bulat, hingga kebutuhan air menyusut.

3. Gradasi agregat: gradasi baik, sehingga kebutuhan air menyusut buat kelecakan yang sama.

4. Kotoran dalam agregat: semakin banyak silt, tanah liat serta lumpur, sehingga kebutuhan air bertambah.

5. Jumlah agregat halus: agregat halus lebih sedikit, sehingga kebutuhan air menurun.

\section{Fly Ash (Abu Terbang)}

Menurut ASTM C-618 (ASTM,1995:304), abu terbang atau fly ash adalah butiran halus sisa hasil pembakaran batubara yang digiling halus. Bahan ini mempunyai warna abu-abu serta butirannya berupa bundar bersifat pozzolanic (bila terkena air akan mengeras). Fly ash diambil dari tambang batubara yang digunakan sebagai sumber bahan utama dalam suatu stasiun tenaga pembangkit yang dihancurkan terlebih dulu sebelum proses pembakaran. Fly ash sebagai bahan pozzolan memiliki ketahanan terhadap agresi sulfat serta air kotor. Kegunaan abu batubara selaku bahan aditif dalam beton ialah selaku pengisi (filler) yang menaikan internal kohesi serta menguragi porositas area transisi yang merupakan bagian terkecil dalam beton, sehingga beton jadi lebih kokoh. Pada usia 7 hari, pergantian fisik abu batubara akan membagikan kontribusi terhadap pergantian kekuatan yang ada pada beton, sebaliknya pada usia 7 - 28 hari, penambahan kekuatan beton karena akibat dari campuran antara ion, dikelilingi dengan molekul semen serta reaksi pozzolan. (Jackson, 1977). [3]

Tabel 5. Komposisi dan klasifikasi fly ash

\begin{tabular}{lccc}
\hline Komponen & Bituminus & $\begin{array}{c}\text { Sub- } \\
\text { bitumis }\end{array}$ & Lignit \\
\hline $\mathrm{SiO}_{2}$ & $20-60$ & $40-60$ & $15-45$ \\
$\mathrm{Al}_{2} \mathrm{O}_{3}$ & $5-35$ & $20-30$ & $20-25$ \\
$\mathrm{Fe}_{2} \mathrm{O}_{3}$ & $10-40$ & $4-10$ & $4-15$ \\
$\mathrm{CaO}$ & $1-12$ & $5-30$ & $15-40$ \\
$\mathrm{MgO}$ & $0-5$ & $1-6$ & $3-10$ \\
$\mathrm{SO}_{3}$ & $0-4$ & $0-2$ & $0-10$ \\
$\mathrm{Na}_{2} \mathrm{O}$ & $0-4$ & $0-2$ & $0-6$ \\
$\mathrm{~K}_{2} \mathrm{O}$ & $0-3$ & $0-4$ & $0-4$ \\
$\mathrm{LO}$ & $10-15$ & $0-3$ & $0-5$ \\
\hline
\end{tabular}

\section{Batu Gamping}

Batu gamping adalah batuan sedimen yang bahan utamanya tersusun dari kalsium karbonat $\left(\mathrm{CaCO}_{3}\right)$ berbentuk mineral kalsit. $\mathrm{Di}$ Indonesia, batu gamping sering disebut dengan istilah batu kapur, sebaliknya istilah luarnya biasa disebut "limestone"

Penelitian sebelumnya yang meneliti tentang variasi Fly ash dan batu gamping antara lain Robby Candra Hasyim (2015), telah melakukan penelitian dengan memanfaatkan Fly ash sebagai subtitusi semen. [4] Dimash Suryadi (1998), "Pengaruh Penambahan Abu Terbang (Fly Ash) PLTU Terhadap Kuat Tekan Beton". [5] Rifanh Gusrianto (2016), "Pengaruh Penambahan Batu Kapur Pada Sebagai Agregat Halus Pada Kuat Tekan Beton Normal". [6] Nurul Rochmah (2016), "Pemanfatan Batu Kapur Didaera Sampahg Madura Sebagai Bahan Penganti Agregat Kasar Pada Campuran Beton". [7]

Tujuan penelitian ini adalah Untuk mengetahui pengaruh penggunaan Fly ash sebagai bahan substitusi semen dan penggunaan batu gamping sebagai agregat kasar untuk mendapatkan sifat mekanik beton seperti nilai kuat tekan, kuat tarik, dan kuat lentur beton dan untuk mengetahui tingkat persentase pemakaian Fly ash yang masih aman digunakan untuk mendapatkan mutu beton yang optimum.

\section{METODE}

Lokasi pengambilan Fly Ash berada padah PT. Makasar Tene JI. Ir. Sutamih No. 38 Kompleks Pergudangan Parangloe Indah Makasar, Sulawesi Selatan, dan pengambilan batu gamping berada padah PT. Semen Tonasa, Desa Biringre, Kacamatan Bungoroh, Kabpaten Pangkep, Proviinsi Sulawesi Selatan

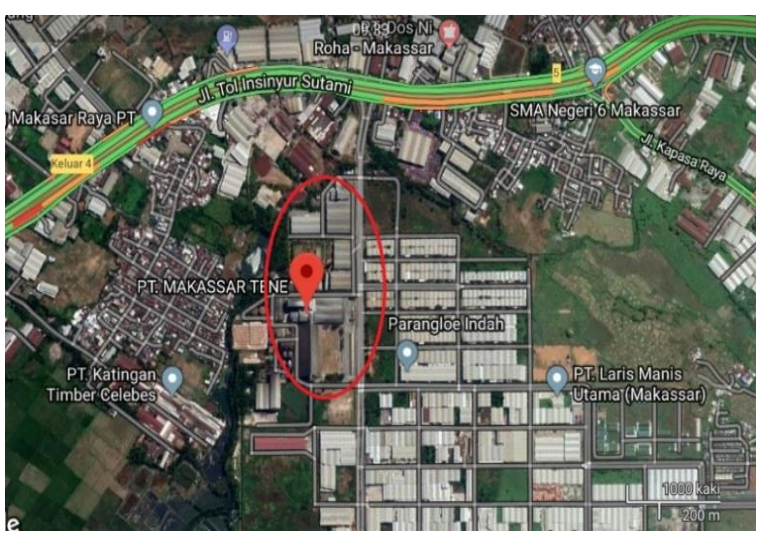

Gambar 1. Lokasi penelitian

\section{Jenis Penelitian}


Jenis penelitian ini adalah penelitian eksprimental di laboratorium seperti pengujian karakteristik agregat kasar dan agregat halus, pengujian kuat tekan, pengujian kuat tarik belah dan pengujian kuat lentur beton.

\section{Pemeriksaan Karakteristik Agregat Halus}

Pemeriksaan karakteristik agregat halus didasarkan pada standar spesifikasi SNI. Hasil pemeriksaan karakteristik agregat halus setelah dilakukan pengujian dan analisis data diperoleh hasil seperti yang terlihat pada tabel di bawah ini :

Tabel 6. Hasil pemeriksaan karakteristik agregat halus

\begin{tabular}{|c|c|c|c|}
\hline $\begin{array}{l}\text { Karak- } \\
\text { teristik }\end{array}$ & Hasil & Interval K & terangan \\
\hline Jumlah Air & 4,4933 & $0,0 \%-5,00 \%$ & Meme- \\
\hline Sat Organik & No.I & $<$ No. $3 \%$ & $\begin{array}{l}\text { Meme- } \\
\text { nuhi }\end{array}$ \\
\hline $\begin{array}{l}\text { Kadar } \\
\text { lumpur }\end{array}$ & 1,6 & $0,20 \%-6,00 \%$ & $\begin{array}{l}\text { Meme- } \\
\text { nuhi }\end{array}$ \\
\hline $\begin{array}{l}\text { Berat Vo- } \\
\text { lume Padat }\end{array}$ & 1,67 & 1,4-1,9 kg/liter & $\begin{array}{l}\text { Meme- } \\
\text { nuhi }\end{array}$ \\
\hline $\begin{array}{l}\text { Berat Vo- } \\
\text { lume Gembur }\end{array}$ & 1,55 & $1,4-1,9 \mathrm{~kg} / \mathrm{liter}$ & $\begin{array}{l}\text { Meme- } \\
\text { nuhi }\end{array}$ \\
\hline $\begin{array}{l}\text { Berat } \\
\text { Jenis SSd }\end{array}$ & 2,56 & $1,60-3,20$ & $\begin{array}{l}\text { Meme- } \\
\text { nuhi }\end{array}$ \\
\hline $\begin{array}{l}\text { Absorsi / } \\
\text { Penyerapan }\end{array}$ & 1,73 & $0,20 \%-2,00 \%$ & $\begin{array}{l}\text { Meme- } \\
\text { nuhi }\end{array}$ \\
\hline $\begin{array}{l}\text { Modulus } \\
\text { Kehalusan }\end{array}$ & 2,49 & $2,20-3,10$ & $\begin{array}{l}\text { Meme- } \\
\text { nuhi }\end{array}$ \\
\hline
\end{tabular}

\section{Pemeriksaan Karakteristik Agregat Kasar}

Pemeriksaan karakteristik agregat kasar pecahan batu gamping didasarkan pada standar spesifikasi SNI. Hasil pemeriksaan karakteristik agregat kasar setelah dilakukan pengujian dan analisis data diperoleh hasil sebagai berikut:

Tabel 7. Hasil pemeriksaan karakteristik agregat

\begin{tabular}{|c|c|c|c|}
\hline & \multicolumn{3}{|c|}{ kasar } \\
\hline $\begin{array}{l}\text { Karak- } \\
\text { teristik }\end{array}$ & Hasil & $\begin{array}{l}\text { Interval } \\
\text { SNI }\end{array}$ & erangan \\
\hline Kadar lumpur & 4,4933 & $3 \quad 0,2 \%-1,0 \%$ & $\begin{array}{l}\text { Meme- } \\
\text { nuhi }\end{array}$ \\
\hline Kadar Air & 0,51 & $0,5 \%-2,0 \%$ & $\begin{array}{l}\text { Meme- } \\
\text { nuhi }\end{array}$ \\
\hline $\begin{array}{l}\text { Berat Vo- } \\
\text { lume Gembur }\end{array}$ & 1,42 & $1,4-1,9 \mathrm{~kg} / \mathrm{Liter}$ & $\begin{array}{l}\text { Meme- } \\
\text { nuhi }\end{array}$ \\
\hline $\begin{array}{l}\text { Berat Vo- } \\
\text { lume Padat }\end{array}$ & 1,67 & 1,4-1,9 kg/Liter & $\begin{array}{l}\text { Meme- } \\
\text { nuhi }\end{array}$ \\
\hline $\begin{array}{l}\text { Berat Vo- } \\
\text { lume Gembur }\end{array}$ & 1,52 & $1,4-1,9 \mathrm{~kg} / \mathrm{Liter}$ & $\begin{array}{l}\text { Meme- } \\
\text { nuhi }\end{array}$ \\
\hline Berat & 2,64 & $1,60-3,20$ & Meme- \\
\hline
\end{tabular}

\begin{tabular}{llll}
\hline Jenis SSD & & nuhi \\
$\begin{array}{l}\text { Absorsi / } \\
\text { Penyerapan }\end{array}$ & 1,23 & $0,20 \%-4,00 \%$ & $\begin{array}{l}\text { Meme- } \\
\text { nuhi }\end{array}$ \\
\hline
\end{tabular}

\section{Pemeriksan Karakteristik Beton}

\section{Kuat Tekan Beton (Berdsarkan SNI 1974 2011)}

Kuat tekan merupakan besarnya beban persatuan luas, sehingga mengakibatkan silinder beton hancur karena beban yang dihasilkan oleh alat uji tekan. [8] Perhitungan kuat tekan beton digunakan persamaan (1) :

Kuat tekan beton $=\frac{P}{A}$

Keterngan :

$P=$ beban maksimal $(\mathrm{N})$

$A=$ luas pempang benda ujih $\left(\mathrm{mm}^{2}\right)$

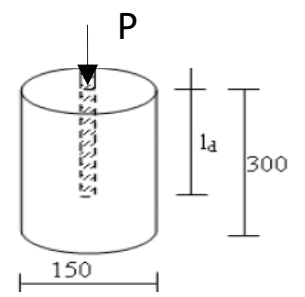

Gambar 2. Uji kuat tekan

\section{Kuat Tarik Belah Beton (Berdasarkan SNI 2491:2014)}

Kuat tarik belah adalah kuat tarik beton yang ditentukan berdasarkan kuat tarik belah dari silinder beton yang ditekan pada sisih panjangnya. Kekuatan tarik belah beton relatif kecil, nilai kuat tekan dan tarik belah beton tidak berbanding lurus. Tegangan tarik yang timbul sewaktu benda uji tarik belah disebut split cylinder stregth atau kuat tarik belah, yang dihitung dengan persaman (2), dengan meknisme pengujian yang ditunjukkan pada gambar berikut. [9]

$T=\frac{2 P}{\pi l d}$.

Dimana :

$T=$ Kekuatan tarik belah $(\mathrm{N} / \mathrm{mm}, \mathrm{MPa})$

$P=$ Besarnya beban $(\mathrm{N})$

$L=$ Panjang bendah ujih $(\mathrm{mm})$

$D=$ Diameter bendah ujih $(\mathrm{mm})$ 

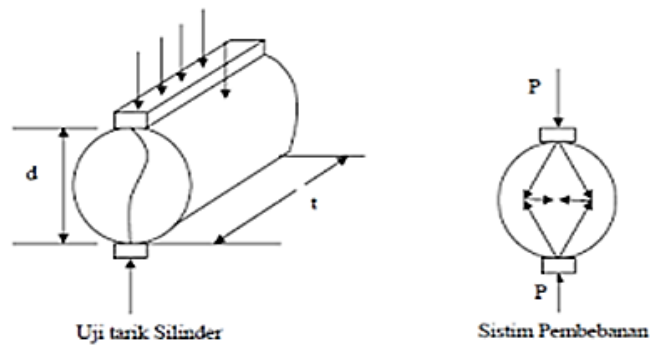

Gambar 3. Uji tarik belah

\section{Pengujian Kuat Lentur Beton (Berdsarkan SNI 4431-2011)}

Kuat lentur merupakan kemampuan dari benda uji balok untuk menahan gaya yang tegak lurus pada pada permukaan benda uji sehingga mengakibatkan balok beton tersebut patah. [10] Kuat lentur beton digunakan dengan persamaan (3) berikut.

$$
\mathrm{f}_{\mathrm{r}}=\frac{\mathrm{PxL}}{\mathrm{bxh}^{2}}
$$

Keterangan :

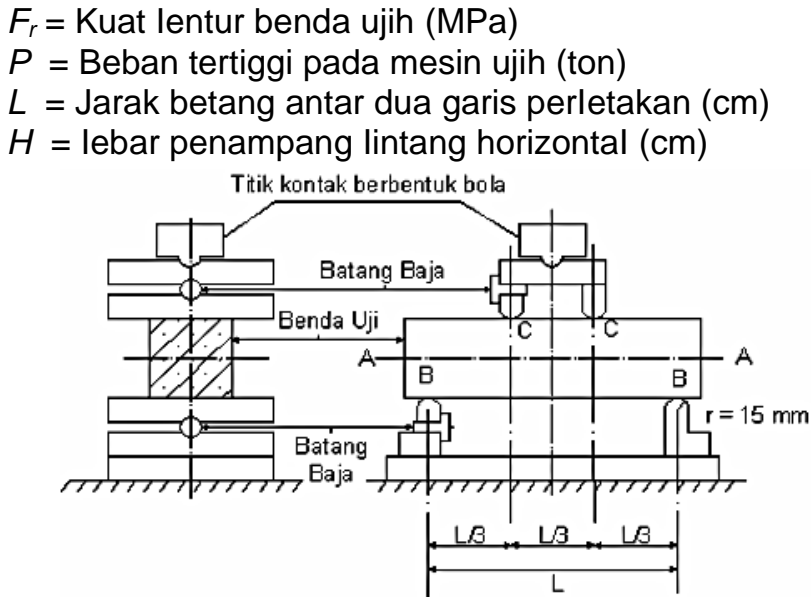

Gambar 4. Benda uji, perletakan dan pembebanan

\section{Komposisi Campuran}

Dari hasil pemeriksaan material dan hasil perhitngan mix design beton dengan metode $\mathrm{ACl}$ 211.2-98 (American Concreteh Institute) diperoleh komposisi campuran beton dapat dilihat pada table berikut.

Tabel 8. Komposisi campuran beton substitusi fly ash silinder dan balok metode $\mathrm{ACl}$ dalam $1 \mathrm{~m}^{3}$

\begin{tabular}{lcccc}
\hline & \multicolumn{4}{c}{ Berat kg/ 1 $\mathrm{m}^{3}$ Silinder } \\
\cline { 2 - 5 } \multicolumn{1}{c}{ Material } & $0 \%$ & \multicolumn{1}{c}{$10 \%$} & $15 \%$ & $20 \%$ \\
\cline { 2 - 5 } Fly Ash & 0 & 0,25 & 0,38 & 0,51 \\
Semen & 2,53 & 2,28 & 2,15 & 2,03 \\
Agregat Halus & 4,57 & 4,57 & 4,57 & 4,57 \\
Agregat Kasar & 6,54 & 6,54 & 6,54 & 6,54 \\
Air & 1,02 & 1,02 & 1,0 & 1,02 \\
\multicolumn{4}{c}{ Berat kg/ $1 \mathrm{~m}^{3}$} & Balok \\
Fly Ash & 0 & 0,65 & 0,97 & 1,29 \\
Semen & 6,45 & 5,81 & 5,49 & 4,32 \\
Agregat Halus & 11,64 & 11,64 & 11,64 & 11,64 \\
Agregat Kasar & 16,66 & 16,66 & 16,66 & 16,66 \\
Air & 2,59 & 2,59 & 2,59 & 2,59 \\
\hline
\end{tabular}

\section{HASIL DAN PEMBAHASAN}

\section{Hasil Pemeriksaan Kuat Tekan Beton}

Prosedur pengujian dilaksanakan berdasarkan (SNI 1974-2011). Pengujian dilakukan pada saat bendah ujih berumur 7 hari, 21 hari, dan 28 hari dengan mengunakan Compressionh Testhing Macthine. Ujih kuat tekan bertujuan untuk megetahui kekuatan beton dalam menerima beban tekan dalam satuan KN. Berikut merupakan hasil perhitungan dari kuat tekan beton dari varisi subtitusi Fly ash $0 \%, 10 \%, 15 \%$ dan $20 \%$.

Tabel 9. Rekapitulasi perhitungan kuat tekan 


\begin{tabular}{|c|c|c|c|c|c|}
\hline $\begin{array}{l}\text { Umur } \\
\text { Pera } \\
\text { watan } \\
\text { (Hari) }\end{array}$ & $\begin{array}{l}\text { Fly } \\
\text { Ash }\end{array}$ & $\begin{array}{l}\text { Beban } \\
\text { P } \\
(\mathrm{N})\end{array}$ & $\begin{array}{l}\text { Kuat } \\
\text { Tekan }\end{array}$ & & \\
\hline \multirow{12}{*}{\multicolumn{2}{|c|}{ (17ning }} & \multirow{3}{*}{$0 \%$} & 280000 & \multirow{3}{*}{17662,5} & \multirow{3}{*}{15,947} \\
\hline & & & 285000 & & \\
\hline & & & 280000 & & \\
\hline & & \multirow{3}{*}{$10 \%$} & 260000 & \multirow{3}{*}{17662,5} & \multirow{3}{*}{14,154} \\
\hline & & & 240000 & & \\
\hline & & & 250000 & & \\
\hline & & \multirow{3}{*}{$15 \%$} & 250000 & \multirow{3}{*}{17662,5} & \multirow{3}{*}{14,060} \\
\hline & & & 250000 & & \\
\hline & & & 245000 & & \\
\hline & & \multirow{3}{*}{$20 \%$} & 290000 & \multirow{3}{*}{17662,5} & \multirow{3}{*}{16,608} \\
\hline & & & 295000 & & \\
\hline & & & 295000 & & \\
\hline \multirow{12}{*}{\multicolumn{2}{|c|}{21}} & \multirow{3}{*}{$0 \%$} & 390000 & \multirow{3}{*}{17662,5} & \multirow{3}{*}{21,892} \\
\hline & & & 380000 & & \\
\hline & & & 390000 & & \\
\hline & & \multirow{3}{*}{$10 \%$} & 365000 & \multirow{3}{*}{17662,5} & \multirow{3}{*}{20,854} \\
\hline & & & 370000 & & \\
\hline & & & 370000 & & \\
\hline & & \multirow{3}{*}{$15 \%$} & 420000 & \multirow{3}{*}{17662,5} & \multirow{3}{*}{23,590} \\
\hline & & & 420000 & & \\
\hline & & & 410000 & & \\
\hline & & \multirow{3}{*}{$20 \%$} & 380000 & \multirow{3}{*}{17662,5} & \multirow{3}{*}{19,910} \\
\hline & & & 375000 & & \\
\hline & & & 370000 & & \\
\hline \multirow{12}{*}{\multicolumn{2}{|c|}{28}} & \multirow{3}{*}{$0 \%$} & 450000 & & \\
\hline & & & 460000 & 17662,5 & 25,761 \\
\hline & & & 455000 & & \\
\hline & & & 420000 & & \\
\hline & & $10 \%$ & 420000 & 17662,5 & 23,968 \\
\hline & & & 430000 & & \\
\hline & & & 490000 & & \\
\hline & & $15 \%$ & 480000 & 17662,5 & 27,554 \\
\hline & & & 490000 & & \\
\hline & & & 420000 & & \\
\hline & & $20 \%$ & 410000 & 17662,5 & 23,213 \\
\hline & & & 400000 & & \\
\hline
\end{tabular}




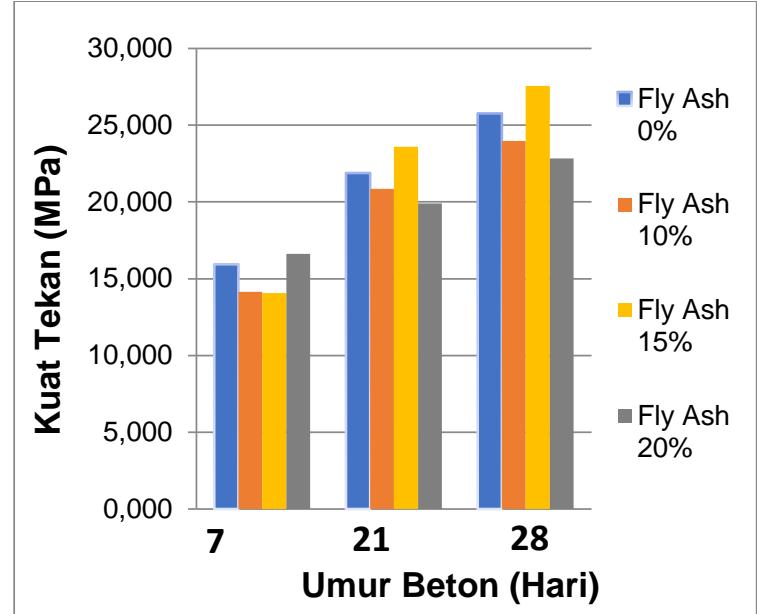

Gambar 5. Hubungan antara umur beton dengan kuat tekan beton

Grafik tersebut menunjukan hubungan antara kuat tekan beton terhadap umhur beton dari beberapa variasi Fly ash dimana kuat tekan rencana adaiah $25 \mathrm{MPa}$. Subtitusi Fiy ash 20\% awalnya tinggi dari subtitusi yang lain pada umur 7 hari, namun pada saat umur 28 hari tidak mencapai kuat tekan rencana. Begitupun sebaliknya dengan subtitusi Fly ash $15 \%$ awalnya sangat rendah, namun pada saat umur 21 hari terus mengalami peningkatan dan pada umur 28 hari mengalami pertambahan nilai dari kuat tekan yang direncanakan

\section{Hasil Pemeriksaan Kuat Tarik Belah Beton}

Pengujian kuat tarik belah beton dilakukan pada saat bendah ujih 28 hari dengan mengunakan Comprhession Testting Macthine untuk mendapatkan beban maksimal yaitu beban pada saat betoh hancur ketika menerima beban tersebut $\left(P_{\text {maks }}\right)$ dalam satuan $\mathrm{KN}$.

Grafik diatas menunjukkan bahwa hubungan antara variasih Fly ash dengan kuat tarik belah beton awalnya mengalami penurunan di subtitusi Fly ash $10 \%$, namun pada saat variasi subtitusi Fly ash 15\% mengalami peningkatan, tetapi pada saat variasi subtitusi Fly ash $20 \%$ terjadi lagi penurunan.
Tabel 10. Rekapitulasi perhitungan kuat tarik belah pada umur 28 hari

\begin{tabular}{|c|c|c|}
\hline Fly Ash & $\begin{array}{c}\text { Beban } \\
\mathbf{P} \text { (Ton) }\end{array}$ & $\begin{array}{c}\text { Kuat Tarik } \\
\text { Belah (MPa) }\end{array}$ \\
\hline \multirow{3}{*}{$0 \%$} & 170000 & \multirow{3}{*}{2,383} \\
\hline & 165000 & \\
\hline & 170000 & \\
\hline \multirow{3}{*}{$10 \%$} & 160000 & \multirow{3}{*}{2,279} \\
\hline & 160000 & \\
\hline & 163000 & \\
\hline \multirow{3}{*}{$15 \%$} & 180000 & \multirow{3}{*}{2,501} \\
\hline & 170000 & \\
\hline & 180000 & \\
\hline \multirow{3}{*}{$20 \%$} & 150000 & \multirow{3}{*}{2,147} \\
\hline & 150000 & \\
\hline & 155000 & \\
\hline
\end{tabular}

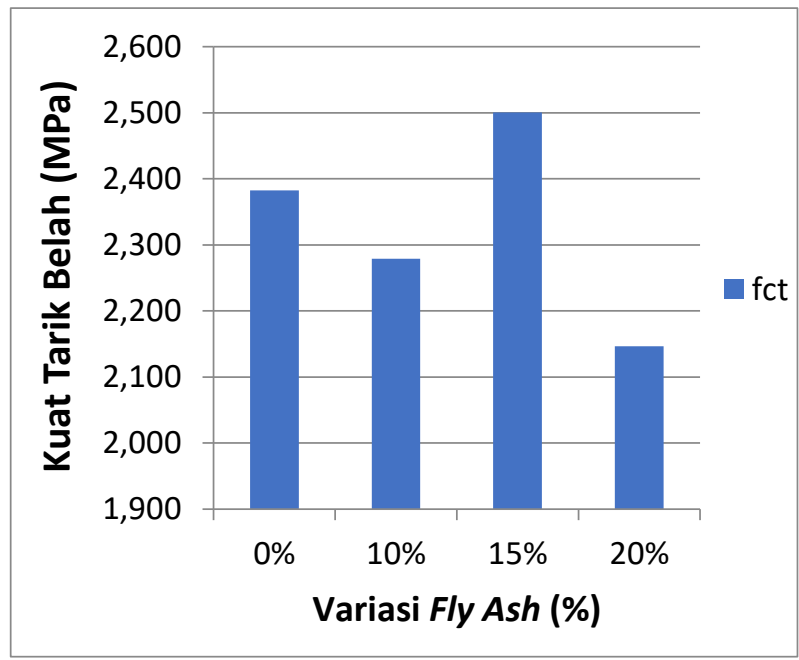

Gambar 6. Hubungan antara variasi fly ash dengan kuat tarik belah

\section{Hasil Pemeriksan Kuat Lentur}

Prosedur pengujian dilaksanakan berdasarkan (SNI 4431-2011), dengan benda uji berbentuk balok degan ukuran $600 \times 150 \times 150 \mathrm{~mm}$. Bendah uji diletakkan pada alat uji lentur dengan dua titik pembebanan.

Tabel 11. Rekapitulasi perhitungan kuat lentur

\begin{tabular}{ccc}
\hline Fly Ash & $\mathrm{P}$ (Ton) & $\begin{array}{c}\text { Kuat Lentur fr } \\
\text { (MPa) }\end{array}$ \\
\cline { 2 - 2 } 0 & 4,583 \\
\cline { 2 - 2 } $10 \%$ & 3,1 & 3,072 \\
\hline
\end{tabular}




\begin{tabular}{lll} 
& 2 \\
\hline \multirow{2}{*}{$15 \%$} & 3 & 4,684 \\
\cline { 2 - 2 } & $\frac{3}{3,3}$ & \\
\hline \multirow{2}{*}{$20 \%$} & $\frac{2}{1,8}$ & 2,720 \\
\cline { 2 - 2 } & 1,6 & \\
\hline
\end{tabular}

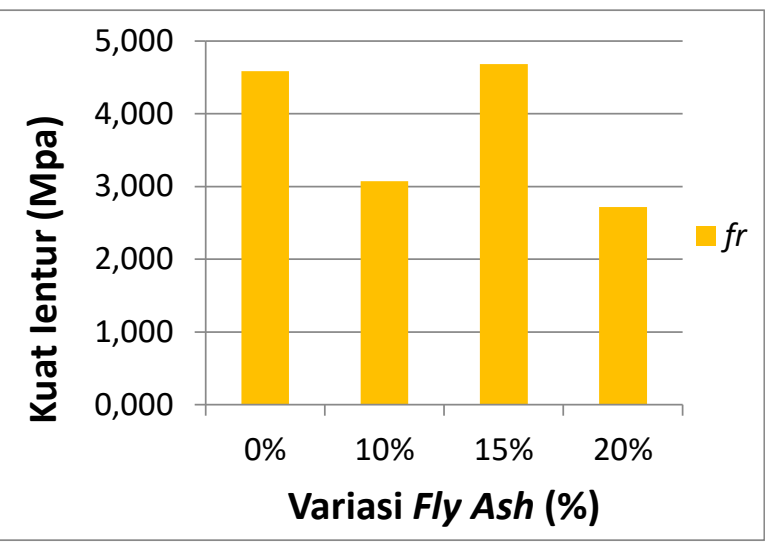

Gambar 7. Hubungan antara variasi fly ash dengan kuat lentur

Grafik diatas menunjukan hubungan antara variasi subtitusi Fly ash dengan kuat lentur dimana pada saat subtitusi Fly ash $10 \%$ dan $20 \%$ mengalami penurunan, tetapi pada saat subtitusi Fly ash $15 \%$ mengalami peningkatan.

\section{KESIMPULAN}

Hasil pengujian kuat tekan dengan subtitusi Fly ash $0 \%, 10 \%, 15 \%$, dan $20 \%$ berturut-turut adalah 25,761 MPa; 23,968 MPa; 27,559 MPa; 23,213 MPa. Hasil pengujian kuat tarik belah pada variasi yang sama berturut-turut adalah 2,383 MPa; 2,279 MPa; 2,501 MPa; 2,147 MPa. Hasil pengujian kuat lentur pada variasi yang sama berturut-turut adalah 4,585 MPa; 3,072 MPa; 4,684 MPa; 2,720 MPa.

Berdasarkan hasil pengujian nilai kuat tekan dari $0 \%$ sampai $10 \%$ mengalami penurunan terhadap beton normal, namun dengan Fly ash $15 \%$ mengalami kenaikan. Akan tetapi pada saat 20\%, kembali mengalami penurunan. Jadi, penggunaan Fly ash dengan subtitusi 15\% masih aman untuk digunakan sebagai bahan substitusi semen dalam pembuatan beton.

\section{DAFTAR PUSTAKA}

[1] SNI 03-2847-2013, Persyratan Beton Struktural untuk Bagunan Gedung. Jakarta: Badan Standrdisasi Nasional.

[2] Antoni dan P. Nugraha, 2007. Teknologi Beton. Yogjakarta: C.V Andi Offset, 2007.

[3] Jackkson, M. G., 1977. Review article. The alkali treathment of sthraw. Anim. Fed Sci. and Tecsh. 2: 105-130.

[4] R.Hasyim, "Pegaruh Abu Terbang Sebagai Bahan Penganti Semen Pada Bata Beton Beragregat Botom Ash," Nov 21, 2017. http://digilib.unila.ac.id/29675/ (diakses Feb 06, 2021).

[5] D. Suryadi, 1998. Pegaruh Penambahan Abu Terbang (Fly Ash) PLTU Terhdap Kuat Tekan Beton. 1998.

[6] R. Gusrianto, "Pengaruh Penambahan Batuh Kapur Pada Sebagai Agegat Halus Pada Kuat Tekah Beton Normal" Jurnal Teknik Sipil ITP, Volume 3. Nomor.2. HIm.17-27.

[7] N. Rochmah, 2016, "Pemanfatan Batuh Kapur Diderah Sampangh Madura Sebgai Bahan Penganti Agrgat Kasar Pada Campuran Beton," JHP17 J. Has. Penelit., Volume. 1, Nomor. 02, Art. no. 02, doi: 10.30996/jhp17.v1i02.936.

[8] SNI 1974-2011, Cara Ujih Tekan Beton Dengan Bendah Uji Silinder. Jakarta: Badan Standarisasi Nasional, 2011.

[9] SNI 2491-2014, Metode Pengujian Kuat Tarik Belah Speshimen Beton Silinder. Jakarta: Badan Standrdisasi Nasional, 2014.

[10] SNI 03-4431-2011, Cara Uji Kuat Lentur Beton Normal dengan Dua Titik Pembebanan. Jakarta: Badan Standarisasi Nasional, 2011. 